\title{
Study on the Inheritance and Development of Folk Culture and Spirit in Woodcut New Year Paintings
}

\author{
Xing Zhou ${ }^{1}$ and Chun Chen ${ }^{2}$ \\ 1 Jingdezhen Ceramic University, Jingdezhen, Jiangxi 333403 \\ ${ }^{2}$ College of Science and Technology, Jingdezhen Ceramic University, Jindezhen, Jiangxi 333000
}

Keywords: Woodcut New Year paintings; Folk culture and spiritual; Expression and inheritance

\begin{abstract}
The art of woodcut New Year plantings is one of the outstanding representatives of folk art in our country. The expression and inheritance of folklore culture and spirit have attracted the attention of relevant researchers. This article elaborates connotation of the folk culture of Chinese woodcut New Year paintings, and then analyzes the psychological characteristics of customers group on the Chinese woodblock New Year paintings, and finally involves the spiritual expression of the Chinese woodcut New Year paintings. The aim is to show the related characteristics of the folklore art in the folk culture and spiritual expression, providing reference for relative researchers.

The continuous deepening of reform and opening up has brought deep impact to the ideas and cultural consciousness of contemporary nationals. A large number of traditional art forms, represented by woodcut New Year paintings, are facing the verge of loss. Although in the past ten years our country have taken a series of pilot projects to protect folk cultural heritage, but still failed to effectively reverse this historical trend. This paper tries to reveal the value and significance of the art of Chinese woodblock New Year from the perspective of the evolution of folk culture and spiritual inheritance.
\end{abstract}

\section{The Folk Culture Connotation of Chinese Woodcut New Year Paintings}

This paper analyzes the development history of traditional Chinese woodcut New Year paintings, which can be divided into four aspects based on the formation process of construction core of Chinese woodcut New Year paintings:

(1) by imprinting the contents of the statue to meet the folk psychology of prevention to bad man and protect family, which is based on meeting the grassroots people's traditional folk psychology, using the symbolic means to show utilitarian ideals.

(2) to play the role of decoration in festive, to create a good atmosphere of public activities, through the woodcut New Year paintings of art works, fully showing people's love and pursuit of life.

(3) to treat the New Year paintings as the carrier, spreading the latest news and information. This type of content arrangements can meet the curious psychology on the novelty and the fresh news, enhancing the atmosphere of times in the performance content of New Year paintings.

(4) concerned about the daily life of ordinary people, and maintain the interaction with current political development and the tide. This kind of content arrangement is the inheritance of the artistic expression in the history of art, showing the stable connection between the Chinese art and the social development and the political thought orientation.

The history of the development of Chinese woodcut New Year paintings is a vivid describing the the influence of the development of the times on the artistic expression and the wish of the artist trying to influence the life of the people.

\section{Consumer Psychology Analysis of the Woodcut New Year Paintings}

First, the diversity of woodcut New Year paintings in the performance are closely related to the diversity of psychological needs of people. Ago, the small businessmen in streets sell the New Year paintings with a variety of characteristics, and often highly consistent with the people's living habits and aesthetic orientation, having a good sales demand. In the different regions, the people tend to 
show the love of different categories of New Year paintings, so the retail hawkers before choosing sales object, should be specific obtain basic awareness about the living customs and conceptual orientation of people in the region, in order to ensure the smooth realization of sales profit targets.

Second, the difference in the genre of the woodcut New Year paintings are closely related to the posting behavior of the people. Woodcut New Year paintings are often based on the differences in the folk function, carefully making design the division on the theme of the New Year paintings, and according to the different situations, the New Year paintings are divided into blessing, city, life, happiness four categories. "Blessing" is the celebration of the painting for the ordinary people of in New Year, mainly to play the role of decoration and create an atmosphere. "City" is generally a commercial store New Year business or when do a new opening to look forward to obtain wealth or the expression of respect for the ancestors. "Shou" is designed for the celebration of the birthday of the family. And "Happiness" is designed for marriage of the family. In addition, people around the country based on their specific using target requirements, often have the special requirements on the paintings in the scale and color matching.

\section{The Spirit Expression of the Chinese Woodcut New Year Paintings}

Woodcut New Year paintings are popular in all parts of our country, not only depends on the performance of their characters with the rich and abundant color, and the title of the works contained the profound auspicious desire, more important reason is that the New Year paintings contained the traditional Chinese Human Spirit. Woodcut New Year pictures can express both the timely and accurate expression of the social life of the present people, but also fully demonstrate the transcendence of the real life situation and the pursuit of the ideal of life, the artistic expression form, and realize the care of the progress path for the real social life.

Making a extension analysis on the development path of Chines New Year paintings, In the period of science and technology having not yet developed, the theme of the idol was popular, and later, with the continuous improvement of the degree of socialization, the people gradually realized the virtual world, began to gradually formed a flexible attitude on the gods that " trust,it exists, don't trust, don't exist". At the same time, some folk art paintings began to introduce the expression of individual and social thoughts in certain times into the works of the New Year paintings, praising the good customs of the people, criticizing the unfair behavior in the social practice environment, for example, advocate to get rich by the labor, and frugal home, filial piety and faith; against lazy, doing nothing but get money, filial justice and so on, which is the reason of the production of the human factors in New Year paintings.

The practical performance of the practical experience, rapid absorption and creative display of the local people' is also an important source of humanistic expression in the works of woodcut New Year paintings. With the continuous expansion of the local area and the continuous infusion of the spiritual characteristics of the times, the content richness of the woodcut New Year paintings are continually growing, in the field of thought, it also showed a rich and objective trend.

In the modern history, the objective reality of the bullying by foreign countries in China has made a great deal of the struggle elements of the spirit in New Year paintings. Since the reform and opening up, the trend of Chinese cultural and artistic creation has been continuously enriched, making New Year paintings evolve toward diversified forms of expression, enhancing the richness of the humanistic spirit of the works.

\section{Conclusion}

This paper focuses on the folklore culture of Chinese woodcut New Year paintings and the expression and inheritance of its spirit, correctly and comprehensively understanding the times and richness characteristics of the art of woodcut New Year paintings in the process of folklore culture and spiritual inheritance, will be of great significance to China's woodcut New Year paintings development. 


\section{Acknowledgements}

Fund Project: This article is the stage result of 2016 Jiangxi Social Science Planning Youth Doctor Foundation project " Study on "Gusu" version of woodcut New Year Paintings and Its Revelation to Cultural Industry" (project number: 16BJ47)

\section{References}

[1] X.G.Wang. Folk culture in the context of Minnan woodblock New Year paintings [D]. Fujian Normal University, 2012-03-20.

[2] J. Liu. The pearl of folk art - Kaixian Zhu Xianzhen woodcut New Year paintings [D]. Fujian Normal University, 2014-04-01.

[3] K. Wang. The evolution of Chinese New Year paintings in 20th century- the spontaneous nature of folk culture [D]. Tianjin University, 2013-05-01.

[4] Q. Li. Baoji folk culture industry heritage and development research-a case of Fengxiang woodcut New Year paintings and painted clay production [J]. Education and Teaching Materials, 2011-07-05. 